\title{
Determination of The Ujrah of Gold Paid Goods at Mandiri Sharia Bank (BSM) Batusangkar
}

\section{Elimartati ${ }^{1}$, Muhammad Rizky Prima Sakti², Hebby Rahmatul Utamy ${ }^{3 *}$, Utari Aulia Rifmadani4}

${ }^{1}$ State Institute for Islamic Studies (IAIN) of Batusangkar, Indone sia e-mail: elimartati@iainbatusangkar.ac.id

2University College of Bahrain, Bahrain e-mail:mrizky@ucb.edu.bh

${ }^{3}$ State Institute for Islamic Studies (IAIN) of Batusangkar, Indonesia e-mail: hebby.ru@iainbatusangkar.ac.id

${ }^{4}$ State Institute for Islamic Studies (IAIN) of Batusangkar, Indonesia e-mail: utariauliarifmadani@gmail.com

*corresponding author

\begin{tabular}{|l|l|l|}
\hline Received: 18-10-2021 & Revised: 13-12-2021 & Accepted: 14-12-2021 \\
\hline
\end{tabular}

Abstract: This study analyzes the cost determination for a gold pawn ujrab at the branch of Banque Syariab Mandiri Batusangkar. This type of research is field researh with qualitative methods. The analys is technique is based on the Fatwa DSN and the theory advanced by Rozalinda. The research results explain that the implementation of the gold pledge at the branch of Bank Syariah Mandiri Batusangkear in accordance with the Standar Operasional Prosedur(SOP) that have been set by the Bank. The costs of administration, maintenance and storage of the pledged goods are determined according to the amount of the customer's loan, the level of fees also depends on the amount of customer loans. So this is not in line with Fatwa DSN No. 25/DSN-MUI/III/ 2002 regarding Rahn, in point four, stated that maintenance and storage charges should not be based on loan amount. It is also not in line with the theory advanced by Rozalinda that the administration of administrative costs is based on the weight of the gold, the cost of maintaining and storing or renting the premises according to the content of the gold.

Abstrak: Penelitian ini menganalisis penentuan biaya ujrah gadai emas di Bank Syariah Mandiri Kantor Cabang Batusangkar. Jenis penelitian ini adalah penelitian lapangan dengan metode kualitatif. Teknik analisis didasarkan pada Fatwa DSN dan teori yang dikemukakan oleh Rozalinda. Hasil penelitian menjelaskan bahwa pelaksanaan gadai emas di Bank Syariah Mandiri Cabang Batusangkar sudah sesuai dengan Standar Operasional Prosedur (SOP) yang telah ditetapkan oleh Bank. Biaya administrasi, pemeliharaan dan penyimpanan barang gadai ditentukan sesuai dengan jumlah pinjaman nasabah, besar kecilnya biaya juga tergantung da ri jumlah pinjaman nasabah. Sehingga hal ini tidak sejalan dengan Fatwa DSN No. 25/DSN-MUI/III/2002 tentang Rahn, pada poin keempat disebutkan bahwa biaya pemeliharaan dan penyimpanan tidak boleh didasarkan pada jumlah pinjaman. Hal ini juga tidak sejalan dengan teori yang dikemukakan oleh Rozalinda bahwa administrasi biaya administrasi didasarkan pada berat emas, biaya pemeliharaan dan penyimpanan atau penyewaan tempat menurut kandungan emas.

Keywords: Determination of Ujrah, Pledge Products, Customer Loans.

\section{INTRODUCTION}

$\boldsymbol{B}_{\text {ank Syariah Mandiri (BSM) Branch }}$ Office (KC) Batusangkar, one of the
Islamic banks whose business must be submissive, obedient and directed by the fatwa of the National Sharia Council of 


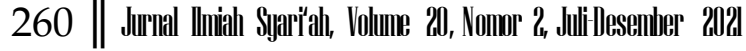

the Indonesian Ulema Council (DSNMUI), which is a reference in. is his activities (Mardani, 2015: 12). One of the financing products is Pawning Gold, a financing product based on a guarantee in the form of gold as an alternative to quickly receive cash intended for individuals (www.mandirisyariah.co.id), at BSM Batusangkar Branch Office with contract of qard, rahn and ijarah.

The Ijarah contract is executed after the mortgage, namely the preservation of the pledged goods by the Murtahin and the binding use of gold storage services as security for customer financing (www.mandirisyariah.co.id). As long as the deposit procedure is still ongoing for the next four months, the customer or Rahin must pay a Ujrah fee for the maintenance and storage costs of Marhun or pawned goods (Ujrah).

Shariah financial institutions to adjust the Ujrah for Shariah pawns and there is a provision to review the Ujrah for Shariah financial institutions in DSN Fatwa No.56/DSN-MUI/V/2007. In this fatwa, the Ujrah review means a review of the Ujrah amount in the Ijarah contract between LKS and the customer after a certain period of time. The operation of the gold deposit product via the Rahn contract refers to the DSN fatwa No.25/DSN-MUI/III/2002 regarding Rahn. All provisions of the Rahn contract have been included in this fatwa, one of which is contained in the fourth general provision, the content of which is that the cost of maintaining and storing Marhun should not be determined according to the amount of the loan (Mardani, 2015: 62). This fatwa also relates to the DSN fatwa on golden Rahn, namely DSN fatwa No.26/DSN-MUI/ 2002 and based on DSN fatwa No.25/DSN-MUI/ III/ 2002 regarding Rahn.
All fatwas created by DSN must be a working reference for any operational activity in Islamic banks. So that the operations of Islamic financial institutions do not deviate from the existing rules. With so many contracts in Islamic banks, banking business requires special supervision in order not to violate the established rules. With good supervision of banks in relation to Sharia rules, this will also affect public trust and work coordination with the supervisory management.

Research on Ujrah on gold lien in Islamic banking has been done quite frequently, and from the identification results there are six studies that are of the same scope. What sets this research apart, however, is that the author conducts an analysis of the determination of the Ujrah of gold pawned goods at BSM KC Batusangkar. The deposit system at BSM is used when the customer needs cash, comes to the bank by gold pawn as security or borrowing money. Then the appraiser evaluates the pawn goods and grants loans to customers. In the case of loaned loans, the pawnbroker (bank) will hold the pawned goods and the customer is obliged to pay the maintenance fee for Marhun or pawned goods. The pawn goods can be taken back by the customer after the loan has been repaid (interview, November 21, 2019).

The maintenance costs (Ujrah) at BSM KC Batusangkar are calculated every 15 days. The amount of fees the customer has to pay for their Ujrah depends on how much the customer borrows. The calculation is based on the amount of the customer loan. The higher the customer's loan amount, the higher the Ujrah fee and other costs such as stamp duty payable. If the customer is unable to settle this, a deferral can be made or the bank has the 
authority to auction the pledged goods and pay the customer's debts. If the auction amount exceeds the customer's loan, this will be refunded to the customer; In the meantime, if the amount of money from the auction is less than the customer's loan, the customer is obliged to pay.

\section{Calculation of Ujrah fees for gold deposit products at Bank Syariah Mandiri KC Batusangkar}

IDR

\begin{tabular}{|c|c|c|c|c|}
\hline No & $\begin{array}{c}\text { Loan } \\
\text { amount }\end{array}$ & $\begin{array}{c}\text { Adm } \\
\text { Fee }\end{array}$ & $\begin{array}{c}\text { Number } \\
\text { of days }\end{array}$ & Ujrah \\
\hline 1 & 1.000 .000 & 25.000 & 15 Hari & 9.000 \\
\hline 2 & 2.000 .000 & 25.000 & 15 Hari & 18.000 \\
\hline
\end{tabular}

Source : Interview with the appraiser from BSM Batusangkar

From the calculation table above it can be seen that the calculation of the Ujrah fee depends on the number of credits given to the customer, so if the number of customer credits is high, the total Ujrah fee is also high. Management fees are determined from the number of loans from clients, that is:

\section{Determination of the deposit administration fee Gold Bank Syariah Mandiri KC Batusangkar}

\begin{tabular}{|l|r|}
\hline \multicolumn{1}{|c|}{ Loan Amount } & $\begin{array}{c}\text { Administration } \\
\text { Fee }\end{array}$ \\
\hline $500.000-20.000 .000$ & 25.000 \\
\hline$>20.000 .000-100.000 .000$ & 80.000 \\
\hline$>100.000 .000$ & 125.000 \\
\hline
\end{tabular}

Source : Interview with the appraiser from BSM Batusangkar

Based on DSN Fatwa No.25/DSNMUI/III/2002 regarding Rahn (pledge) contracts in the general provisions 4 that the level of maintenance and storage costs for Marhun should not be determined on the basis of the loan amount. And based on DSN Fatwa No.26/DSN-MUI/III/ 2002 on the Golden Rahn. Based on the foregoing, the research aims to determine the Ujrah for gold pawns at BSM KC Batusangkar to investigate.

\section{RESEARCHMETHODS}

The research method used in this paper is qualitative, with data sources from pawning staff at BSM KC Batusangkar, and customers related to this research (primary), and brochures, ujrah calculation notes and indirect observations to the Bank Mandiri Syariah website (secondary data). ). The analysis was carried out by descriptive analysis. Connecting each data obtained using the theory of Miles and Huberman, includes three activities. First, reducing data by providing a sharper view of the results of a study, carried out during the study from the beginning to the end of the study. Second, presenting the data that has been collected. And Third, draw conclusions as complete information that can be verified.

\section{RESULT AND DISCUSSION}

Gold Pawn Implementation and Ujrah Fee Determination for Gold Pledge Goods at Bank Syariah Mandiri Batusangkar

One of the new products launched in January 2018 is gold pawn financing at BSM Batusangkar. This financing uses gold as an item used as collateral for a certain period to obtain financing facilities, along with Qard, Rahn and Ijarah contracts. This financing is seen as a solution to meet the financing needs of clients with a simple and fast (one day) process.

According to Hilga Ingriyani, BSM $\mathrm{KC}$ Batusangkar pledging staff member, 


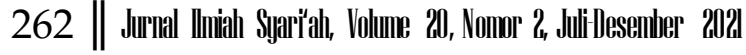

the gold pawn product has the advantage of high estimate $(80 \%)$, quick processing, affordable ujrah and Pledged gold is stored by the bank with a storage gold standard. The SOP for gold pawn products at BSM, begins with the customer's approval to fulfill the conditions offered by the bank, the main requirements are an identity (KTP) and the gold to be estimated at a minimum 16 karat and not white gold, the evaluation is done by physical analysis and chemical analysis (with test water) as well as wet and dry density analysis (weighing), then disbursement is carried out after there is an agreement with the signing of the contract on the gold pledge between the two parties. Withdrawals are made in cash and non-cash (via previously opened customer accounts).

Regarding the agreed collateral period, when due, the client can provide funds to the account and extend it one week before the due date. Checks will be carried out at the beginning of each month, if it is close to the deadline, the customer will be contacted for confirmation. The extension of the term can be done automatically or after payment on the due date.

Determination of the Ujrah for the gold pawn at the Bank Syariah Mandiri Batusangkar

The charges paid by the customer for the pledge they have set up consist of administrative charges, ujrah charges for storage and maintenance, and insurance charges. According to the results of the interview with the pawnbroker of the branch of Bank Syariah Mandiri Batusangkar regarding the determination of the ujrah fees for the pledged goods, that the initial cost, namely the administrative fees paid by the client based on the client's loan amount, is:

\section{Determination of administration fees of the gold pawn for the Bank Syariah Mandiri KC Batusangkar}

IDR

\begin{tabular}{|l|r|}
\hline \multicolumn{1}{|c|}{ Loan Amount } & $\begin{array}{c}\text { Administrativ } \\
\text { e Costs }\end{array}$ \\
\hline $500.000-20.000 .000$ & 25.000 \\
\hline$>20.000 .000-100.000 .000$ & 80.000 \\
\hline$>100.000 .000$ & 125.000 \\
\hline
\end{tabular}

Source : Interview with the appraiser from BSM Batusangkar

Next is the ujrah fee paid by the customer at the time of payment, and the calculation is done in fifteen days depending on the customer's usage period. The cost of this ujrah depends on the number of customer credits, is:

Calculation of Ujrah's Fee for Gold Pledge Products at Bank Syariah Mandiri KC Batusangkar

\begin{tabular}{|c|l|l|c|c|}
\hline No & $\begin{array}{l}\text { Loan } \\
\text { Amount }\end{array}$ & $\begin{array}{l}\text { Adm } \\
\text { Costs }\end{array}$ & $\begin{array}{l}\text { Number } \\
\text { of days }\end{array}$ & Ujrah \\
\hline 1 & 1.000 .000 & 25.000 & 15 Hari & 9.000 \\
\hline 2 & 2.000 .000 & 25.000 & 15 Hari & 18.000 \\
\hline
\end{tabular}

Source : Interview with the appraiser from

$$
\text { BSM Batusangkar }
$$

The last charges paid by the customer are the insurance charges. Insurance costs are used to insure At Bank Syariah Mandiri Batusangkar branch, insurance costs are deducted from administrative costs. As an example of simulating the calculation of costs paid by customers, we can cite:

Example : gold pawn, one gold.

Administrative Costs $=25,000$ IDR (depending on the amount of customer financing).

Duration of use of the pawn = one month (two periods). In the BSM pledging 
provisions, a period is equal to fifteen days.

Ujrah per month $=\operatorname{Rp} 18.000$ per month.

Ujrah by period $=\operatorname{Rp} 9.000$ per 15 days.

Based on the aggregate information that the author obtained through the results of the interviews, in particular with regard to the ujrah of the pledged goods, the client will be charged a fee for the pledge made on the basis of the amount of the client's loan. The higher the number of customer loans, the higher the fees that must be paid by the customer.

Implementation of Ujrah's determination for property pawn in gold to BSM KC Batusangkar in view of Sharia banking on DSN Fatwa regarding Rahn

Gold pawn Financing at BSM KC Batusangkar is one of the products which helps clients in financial matters with quick and easy process. This product uses three types of contracts, that is Qard contract, Rahn contract and Ijarah contract. According to the results of the interviews, each of these contracts has a function in this single product:

a. Qard contract, for binding financing from banks to customers

b. Rahn contract for gold mandatory as collateral for customer financing

c. Ijarah contract to bind the use of gold storage services as collateral for customer financing (BSM KC Batusangkar pawn document).

Standard Operating Procedures (SOP) consist of several processes, that is:

a. Compliance with customer requirements

The conditions that customers must meet in order to finance this gold pawn are in the form of an identity card (KTP) and a customer account. However, if the client's financing exceeds fifty million rupees, it is necessary to attach a NPWP. Then the customer fills out the form provided by the bank. Judging by the process of meeting requirements by this customer, it is in accordance with established procedures

b. Estimate of pledged property

In the appraisal process, based on a field examination, this appraisal was carried out in three stages of the appraisal method so that accurate test results were obtained for the gold pledged by the customer.

c. Agreement

This approval is materialized by the signature of the client who pledged the gold and a sign from the bank that he has approved the financing of the gold pawn made.

d. Disbursement of funds

In this disbursement of funds, clients can withdraw funds from accounts held by clients who have signed up for gold pledge financing. Withdrawals can be made by customers through cashiers so that it is easier for customers later (Results of interviews with staff of lender BSM KC Batusangkar)

Ujrah's review of pawn goods at BSM KC Batusangkar includes:

a. Administration fees, which are calculated based on the customer's loan amount. But in theory, the administrative fee should be set based on the estimated price of gold held by the customer.

\section{Determination of administration fees of the gold pawn for the Bank Syariah Mandiri Batusangkar}

IDR

\begin{tabular}{|l|r|}
\hline \multicolumn{1}{|c|}{ Loan Amount } & \multicolumn{1}{c|}{ Adm Costs } \\
\hline $500.000-20.000 .000$ & 25.000 \\
\hline$>20.000 .000-100.000 .000$ & 80.000 \\
\hline$>100.000 .000$ & 125.000 \\
\hline
\end{tabular}


Source : Interview with the appraiser from BSM Batusangkar

b. Maintenance and storage costs of the pawn goods. Maintenance fees are also calculated based on the customer's loan amount. This also does not work according to the theory of costing in the Fatwa of DSN-MUI No.25/DSNMUI/III/2002 with Rahn, according to which the cost of maintenance and storage of the pawn goods should not be not be calculated on the basis of the loan amount.

\section{Calculation of Ujrah's Fee for Gold} Pledge Products at Bank Syariah Mandiri KC Batusangkar

IDR

\begin{tabular}{|c|c|c|c|c|}
\hline No & $\begin{array}{c}\text { Loan } \\
\text { Amount }\end{array}$ & $\begin{array}{c}\text { Adm } \\
\text { Costs }\end{array}$ & $\begin{array}{c}\text { Number } \\
\text { of days }\end{array}$ & Ujrah \\
\hline 1 & 1.000 .000 & 25.000 & 15 Hari & 9.000 \\
\hline 2 & 2.000 .000 & 25.000 & 15 Hari & 18.000 \\
\hline
\end{tabular}

Source: Interview with the appraiser from BSM Batusangkar

In terms of maintenance and storage costs for the marhun, the pawnbroker rents premises to store or entrust the pledged goods and the bank determines the costs to be borne by the pawnbroker. The determination of fees depends on the rules on the bank's decision regarding the fees paid by the lender or customer. The fixing of the cost of the pawn goods from the perspective of the Islamic banking, according to Rozalinda, is carried out on the basis of the estimate of gold:

1) Application fees, billed in stages according to the weight of the jewel (gold), and payment is made in advance.

\section{Gold Pawn Administration Fees}

\begin{tabular}{|c|c|c|}
\hline Group & Gold weight & $\begin{array}{c}\text { Administrat } \\
\text { ive Costs }\end{array}$ \\
\hline
\end{tabular}

\begin{tabular}{|c|l|l|}
\hline 1 & $\begin{array}{l}2 \text { gram s.d 100 } \\
\text { gram }\end{array}$ & $\operatorname{Rp~12.500,00}$ \\
\hline 2 & $\begin{array}{l}<100 \text { gram s.d } \\
200 \text { gram }\end{array}$ & $\operatorname{Rp~15.000,00}$ \\
\hline 3 & $\begin{array}{l}<200 \text { gram s.d } \\
300 \text { gram }\end{array}$ & $\operatorname{Rp~17.500,00}$ \\
\hline 4 & $<300$ gram & $\operatorname{Rp~20.000,00}$ \\
\hline
\end{tabular}

Sumber : Rozalinda, 2016

2) The cost of renting a room, paid at the time of loan repayment (financing), is calculated based on the weight and gold content of the mortgage for the storage / pledging period per 10 days.

\section{Gold Pawn Place Rental Fee}

Sumber: Rozalinda, 2016

\begin{tabular}{|c|l|c|c|c|}
\hline \multirow{2}{*}{ No } & \multirow{2}{*}{$\begin{array}{l}\text { Gold } \\
\text { measure }\end{array}$} & \multicolumn{3}{|c|}{$\begin{array}{l}\text { Space Rental Fee Per } \\
\text { Gram (IDR) }\end{array}$} \\
\cline { 3 - 5 } & & $\begin{array}{l}\text { Per 10 } \\
\text { days }\end{array}$ & $\begin{array}{l}\text { Per } \\
\text { month }\end{array}$ & $\begin{array}{l}\text { Per 4 } \\
\text { month }\end{array}$ \\
\hline 1 & $\begin{array}{l}\text { Gold } \\
\text { bar } \\
\text { karat }\end{array}$ & 1.455 & 4.365 & 17.460 \\
\hline 2 & 24 karat & 1.670 & 5.010 & 20.040 \\
\hline 3 & 23 karat & 1.600 & 4.800 & 19.200 \\
\hline 4 & 22 karat & 1.535 & 4.605 & 18.420 \\
\hline 5 & 21 karat & 1.465 & 4.395 & 17.580 \\
\hline 6 & 20 karat & 1.395 & 4.185 & 16.740 \\
\hline 7 & 19 karat & 1.325 & 3.975 & 15.900 \\
\hline 8 & 18 karat & 1.255 & 3.765 & 15.060 \\
\hline 9 & 17 karat & 1.185 & 3.555 & 14.220 \\
\hline 10 & 16 karat & 1.115 & 3.345 & 13.380 \\
\hline
\end{tabular}

In this study, the authors can conclude that in the determination of ujrah according to the number of loans from the perspective of Islamic banking carried out at BSM KC Batusangkar, it is carried out according to the number of customer loans, according to of the amount borrowed by the customer. for mortgage, therefore the fees paid by the customer depend on the amount of the loan. 
In addition, the fees paid by customers (ujrah) are known as follows:

1. The bank acts like a murtahin, so the bank has the right to keep the pledged goods until they are repaid..

2. The maintenance and storage of the marhun is basically the obligation of the rahin, but it can be carried out by the murtahin so that the rahin or the customer pays the cost of maintaining and storing the marhun

3. Administration fees are paid by the customer in tiered categories based on the customer's loan amount. The ujrah fee for maintaining and storing collateral is also paid based on the calculation of the customer's loan amount. The last is the insurance commission taken by the bank from the administrative costs.

4. If the client is not able to pay the obligation when due, an automatic extension can be made according to the client's wishes, while if it has arrived in the new year, a new proof of collateral will be made again.

The DSN-MUI fatwa must indeed be respected by all the economic actors of the Sharia and the financial institutions of the Sharia. DSN's consideration in stipulating a fatwa on Rahn is a form of service provided to meet the financial needs of the public by mortgaging property as security for their debts. Based on the Fatwa regarding Rahn, it is pointed out that loans by pledging property as collateral for a debt in the form of rahn are permitted with the provisions regarding ujrah contained in the fourth pillar, that is: The amount of maintenance and storage costs for the marhun should not be determined based on the loan amount.

Regarding the analysis of the cost of the ujrah, the focus is more on the fatwa regarding the rahn in point four which says that the amount of maintenance and storage costs for the marhun should not be estimated on the basis of the loan amount. The cost calculation here can be done based on the estimated gold pawn by the customer. The final analysis the author obtained concerned the determination of ujrah for the gold pawn goods at BSM KC Batusangkar against fatwa No.25/DSN$\mathrm{MUI} / \mathrm{III} / 2002$, is that there is a gap between the practice of determining the ujrah of the goods pledged and the fatwa concerning the amount of storage and maintenance costs

\section{CONCLUSION}

In the implementation of the gold pawn which was carried out at BSM KC Batusangkar in the process of meeting customers' requirements, the valuation of pawn goods, approval and disbursement of funds was in accordance with the SOP that had been drawn up so that it was performed correctly. To determine the cost of the pledge made at BSM KC Batusangkar, it is based on the customer's loan amount

In practice, the determination of the ujrah of the goods pledged to BSM KC Batusangkar, i.e. the administrative, maintenance and storage costs of the pledged goods is determined by calculating the amount of customer loans or financing of customers so that they do not comply with the provisions of national law. Sharia Council Fatwa No.25/DSNMUI/III/2002 regarding Rahn that in the fatwa it is stated that "the cost of maintaining and storing the marhun should not be based on the amount of the loan".

\section{REFERENCES}


Adam, P. (2018). Fatwa-Fatwa Ekonomi Syariah: Konsep, Metodologi, dan Implementasinya Pada Lembaga Keuangan Syariah. Jakarta: AMZAH. Akhmad, M. (2016). Hukum Perbankan Syariah. Depok: PT RajaGrafindo Persada.

Ali, Z. (2008). Hukum Gadai Syariah. Jakarta: Sinar Grafika

Anshori, A. G. (2006). Gadai Syariah di Indonesia. Yogyakarta: Gadjah Mada University Press.

Antonio, M. S. (2001). Bank Syariah Dari Teori ke Praktek. Jakarta: Gema Insani Pers.

Anwar, S. (2007). Hukum Perjanjian Syariah: Studi Tentang Teori Akad

Dalam Fikih Muamalat. Jakarta: Raja Grasindo Persada.

Arianti, F. (2014). Fikih Muamalah II. Batusangkar: STAIN Batusangkar Press.

Burhanuddin, S. (2011). Hukum Bisnis Syariah. Yogyakarta: UII Press.

Darsono dkk. (2017). Perbankan Syariah di Indonesia Kelembagaan dan Kebijakan Serta Tantangan ke Depan. Jakarta: PT Raja Grafindo Persada.

Fatwa Dewan Syariah Nasional No. 25/DSN-MUI/III/2002 tentang Rahn.

Fatwa Dewan Syariah Nasional No. 26/DSN-MUI/III/2002 tentang Rahn Emas

Fatwa Dewan Syariah Nasional No. 56/DSN-MUI/V2007 tentang Ketentuan Review Ujrah Pada Lembaga Keuangan Syariah.

Fatwa Dewan Syariah Nasional No. 9/DSN-MUI/VI/2000 tentang Ijarah.

Hasan, A. (2003). Berbagai Macam Transaksi Dalam Islam. Jakarta: PT Raja Grafindo Persada.
Huda, N. \& Heykal, M. (2010). Lembaga Keuangan Syariah Tinjauan Teoritis dan Praktis. Jakarta: Kencana.

Idri. (2015). Hadis Ekonomi: Ekonomi Dalam Perspektif Hadis Nabi. Jakarta: Prenadamedia Group.

Iska, S. \& Ifelda, N. (2016). Manajemen Lembaga Keuangan Syariah Non Bank: Teori, Praktek dan Regulasi. Padang: CV. Jasa Surya.

Iska, S. (2012). Sistem Perbankan Syariah di Indonesia. Yogyakarta: Fajar Media Press.

Karim, A. (2016). Bank Islam Analisis Fiqih dan Keuangan. Jakarta: PT Raja Grafindo Persada.

Karim, H. 1997. Fikih Muamalah. Jakarta: Grafindo Persada

Mardani. (2015). Aspek Hukum Lembaga Keuangan Syariah di Indonesia. Jakarta: Prenadamedia Group.

Mufid, M. (2016). Ushul Figh Ekonomi dan Keuangan Kontemporer. Jakarta: Prenadamedia Group.

Nawawi, F. I. (2017). Pelaksanaan Gadai Emas Pada Perbankan Syariah (Studi Pada BNI Syariah Kota Semarang). Diponegoro Law Jurnal, 6 (1).

Nurhasanah, N. dkk. (2017). Hukum Perbankan Syariah: Konsep dan Regulasi. Jakarta: Sinar Grafika.

Rozalinda. (2016). Fikih Ekonomi Syariah Prinsip dan Implementasinya pada Sektor Keuangan Syariah. Jakarta: PT Raja Grafindo Persada.

Sabiq, S. (2003). Fiqih Sunnah Jilid III. Beirut: Dar Al Fikr.

Sahrani, S. (2011). Fikih Muamalah. Bogor: Ghalia Indonesia.

Sam, I. (2014). Himpunan Fatwa Keuangan Syariah Dewan Syariah Nasional MUI. Jakarta: Erlangga. 
Sholahuddin. (2006). Lembaga Ekonomi

Dank Keuangan Islam. Surakarta:

Muhammadiyah University Press

Sinn, A. dkk. (2008). Manajemen Syariah. Jakarta: PT Raja Grafindo Persada.

Soemitra, A. (2010). Bank dan Lembaga Keuangan Syariah. Jakarta: Kencana.

Sugiyono. (2018). Metode Penelitian Kuantitatif, Kualitatif dan RED. Bandung: Alfabeta.

Suhardi. (2018). Pengantar Manajemen dan Aplikasinya. Yogyakarta: Penerbit Gava Media.

Sutedi, A. (2011). Pasar Modal Syariah Sarana Investasi Keuangan

Berdasarkan Prinsip Syariah. Jakarta : Sinar Grafika.

Syafe'i, R. (2008). Figh Muamalat. Bandung: Pustaka Setia.

UU No. 21 Tahun 2008 tentang Perbankan Syariah

Wardi, M. A. 2015. Fiqh Muamalat. Jakarta: Bumi Aksara.

www.mandirisyariah.co.id

Zuhaili, W. (2011). Al Figh Al Islami wa Adillatuhu. Jakarta: Gema Insani. 